Research Paper

\title{
Pathological Characterization Of IFNAR(-/-) Mice Infected With Bluetongue Virus Serotype 4
}

\author{
Alejandro Marín-López ${ }^{1}$, Roberto Bermúdez², Eva Calvo-Pinilla ${ }^{1}$, Sandra Moreno스, Alejandro Brun ${ }^{1}$, Javier \\ Ortego ${ }^{1 \bowtie}$ \\ 1. INIA-CISA, Ctra. Algete-El Casar, Valdeolmos, 28130 Madrid, Spain; \\ 2. Departamento de Ciencias Clínicas Veterinarias, Facultad de Veterinaria, Universidad de Santiago de Compostela, 27002 Lugo, Spain. \\ $\bowtie$ Corresponding author: Dr. Javier Ortego. INIA-CISA, Ctra. Algete-El Casar, Valdeolmos, 28130 Madrid, Spain. Tel: +34 916202300; Email: ortego@inia.es.
}

() Ivyspring International Publisher. Reproduction is permitted for personal, noncommercial use, provided that the article is in whole, unmodified, and properly cited. See http://ivyspring.com/terms for terms and conditions.

Received: 2016.01.14; Accepted: 2016.06.11; Published: 2016.11.24

\begin{abstract}
Bluetongue virus (BTV) replicates in lymphoid tissues where infected mononuclear leukocytes secrete proinflammatory and vasoactive mediators that can contribute to bluetongue (BT) pathogenesis. Using the well-characterized IFNAR(-/-) mice animal model, we have now studied the histopathology and dynamics of leukocyte populations in different target tissues (spleen, thymus, and lung) during BTV-4 infection by histological and immunohistochemical techniques. The spleen and thymus of BTV-4 infected mice showed severe lymphoid depletion on H\&E stained sections. This finding was confirmed by IHC, showing moderate decreased immunopositivity against $C D 3$ in the thymus, and scarce immunoreactivity against $C D 3$ and $C D 79$ in the rest of the white pulp in the spleen, together with an increase in MAC387 immunostaining. BTV-4 infection also induced the expression of active caspase- 3 in the spleen, where apoptotic debris was observed by H\&E. A dramatic increase in iNOS immunoreactivity associated to necrotic areas of the white pulp was observed, being less noticeable in the thymus and the lung. The induction of pro-inflammatory cytokines in tissues where BTV replicates was evaluated by measuring transcript levels by RT-qPCR. BTV-4 infection led to enhance transcription of IFN- - , TNF, IL-6, IL-12-p40, and IL-1 $\beta$ mRNA in the thymus, spleen and lung, correlating with the level of virus replication in these tissues. Disease progression and pathogenesis in IFNAR(-/-) mice closely mimics hallmarks of bluetongue disease in ruminants. IFNAR(-/-) mice are a good choice to facilitate a faster advance in the field of orbiviruses.
\end{abstract}

Key words: bluetongue virus, IFNAR(-/-) mice, leukocyte, cytokine, pathology.

\section{Introduction}

Bluetongue virus (BTV) causes bluetongue, a major hemorrhagic disease of ruminants. The virus, consisting of 27 different serotypes [1-3], is transmitted to its vertebrate host by a few species of biting midges of the Culicoides genus (Diptera: Ceratopogonidae) [4]. Natural BTV infection of ruminants begins with intra-dermal introduction of the virus during the blood feeding of an infected insect. The inoculated virus first infects mononuclear inflammatory cells, including dendritic cells, and it then drains to the local lymph node where further replication occurs prior to the infected cells migrating to the tissues that have been described as the secondary sites of BTV replication such as the lungs, spleen, thymus, and lymph nodes [5-9].

Virus replication in mononuclear phagocytic, dendritic, and endothelial cells (ECs) and the response of these cells to the infection are critical in the pathogenesis of BTV [8, 10-12]. The inflammatory and vasoactive mediators released by BTV-infected ruminants have been proposed as responsible of the increased vascular permeability that characterizes severe BT; specifically, vasoactive mediators released from BTV-infected cells exert paracrine effects that increase the permeability of adjacent blood vessels [13]. Experimental findings have shown that 
pro-inflammatory cytokines such as IL-12, IFN- $\gamma$, IL-8, and TNF, as well as vasoactive mediators produced in monocytes/macrophages and cytotoxic lymphocytes (CTLs) are likely involved in BTV pathogenesis and viral kinetics [14]. Thus, the endothelial injury observed during BTV infection could be due to the direct pathogenic effect of BTV infection on endothelial cells or to a response to inflammatory mediators released by virus-infected cells. Similarly, production of pro-inflammatory cytokines by macrophages has been shown to contribute to the pathogenesis of human viral hemorrhagic fevers [15-17].

To date, few in vivo studies have been carried out to clarify the source and the role of pro-inflammatory cytokines in the appearance of lesions during BTV infection using tissue samples from naturally or experimentally infected ruminants [18]. Because BTV natural hosts are expensive and require specialized animal facilities with biosafety level 3, the IFNAR(-/-) mouse is a good model to study many aspects of pathogenesis, virulence, vaccine efficacy and immune response to BTV [19-26]. In this animal model, we can closely follow infection and disease progression in a short period of time.

The main objective of this work was to study in the IFNAR(-/-) mice model several pathological aspects reported in BTV infected ruminants. The histopathology and dynamics of monocytes/ macrophages, and $\mathrm{B}$ and $\mathrm{T}$ lymphocytes of infected mice were analyzed by means of histopathological and immunohistochemical methods on tissue samples from IFNAR(-/-) mice experimentally infected with BTV-4. Moreover, the presence of inducible nitric oxide synthase (iNOS), that modulates adaptive immune responses, and active caspase-3, an indicator of apoptosis, were also analyzed in these tissues by immunohistochemistry. This study was completed with the experimental analysis of the induction of expression of pro-inflammatory cytokines (IL-1 $\beta$, IL-12, IFN- $\gamma$, IL-6, and TNF) in the infected tissues to better understand the pathology of BTV.

\section{Materials and Methods}

\section{Virus and cells}

KC cells, obtained from $C$. sonorensis larvae, were grown in Schneider's insect medium supplemented with 10\% FBS. BTV serotype 4 (MOR2009/09) (BTV-4(M)), isolated from sheep blood in KC insect cells [27], was used in the experiments. KC cells and BTV-4(M) were generously provided by Professor Peter Mertens (The Pirbright Institute, UK).

\section{Mice}

IFN $\alpha / \beta R^{\circ} / \mathrm{o}$ IFNAR(-/-) 129/Sv mice and wild type $129 / \mathrm{Sv}$ mice were purchased from B\&K Universal Ltd UK. Eight-week old male mice were used throughout the study. Mice were maintained under pathogen-free conditions and allowed to acclimatize to the biosafety level 3 (BSL3) animal facility at the Centro de Investigación en Sanidad Animal, INIA, Madrid, for 1 week before use. All experiments with live animals were performed under the guidelines of the European Community (86/609) and were approved by the ethical review committee at the Centro de Investigación en Sanidad Animal of the Instituto Nacional de Investigaciones Agrarias (Permit number: CEEA 2010-034) . All efforts were made to minimize suffering as well as the number of animals employed.

\section{Animal inoculation and processing of samples}

Mice were infected subcutaneously with different doses of virus. Mice were examined for clinical signs daily. Whole blood was collected in EDTA from all animals at regular intervals after inoculation. At varying times post-infection, several mice were sacrificed, perfused with phosphate-buffered saline (PBS), and several organs (spleen, lung, and thymus, and lymph nodes) were harvested. Tissues were homogenized in PBS using a Tissue Lyser homogenizer (Qiagen). The viruses were released from whole blood and homogenized tissues by three freeze/thaw cycles. The amount of infectious virus was measured by real-time RT-qPCR specific for BTV segment 5 as described by Toussaint et al. (2007).

\section{Blood measurements}

A multiparameter, Autohematology Analyzer (BC-5300 Vet, Mindray, China) was used to determine the total and differential cell counts in blood collected into EDTA tubes.

\section{Histopathology and immunohistochemistry}

Samples from different tissues and organs (spleen, lung, and thymus) were fixed in 10\% buffered formalin ( $\mathrm{pH}$ 7.2) for histopathological studies. After fixation, samples were dehydrated through a graded series of alcohol to xylol and embedded in paraffin wax. Sections of $4 \mu \mathrm{m}$ thick from paraffin wax blocks were cut and stained with hematoxylin and eosin $(\mathrm{H}$ \& E) for histopathological analyses.

For immunohistochemical procedures, $3 \mu \mathrm{m}$ thick sections were mounted on slides coated with silane and dried at room temperature (RT) for $24 \mathrm{~h}$. Unless otherwise stated, all incubations were performed at RT in a humid chamber and the slides were washed three times for $5 \mathrm{~min}$ in $0.1 \mathrm{M}$ PBS 
containing $0.05 \%$ Tween-20 (Sigma-Aldrich) after each incubation. The endogenous peroxidase activity was inhibited by incubating sections with peroxidase blocking reagent (Dako, Denmark) for $1 \mathrm{~h}$. The primary antibodies and immunohistochemical procedures are listed in Table 1. After incubation with the primary antisera, sections were incubated for 30 min with the secondary antibody, either anti-rabbit or mouse En Vision+ System Labelled Polymer-HRP (Dako). Peroxidase reaction was developed using 3.3'diaminobenzidine tetrahydrochloride as chromogen diluted 1:50 in a specific buffer (Dako, Denmark). Finally, sections were counterstained with hematoxylin, dehydrated and coverslipped with DePex mounting medium. Negative controls were obtained substituting the primary antibody by an irrelevant antibody or by PBS. Suitable tissues from other species were employed as positive controls.

\section{Total RNA extraction and first-strand cDNA preparation}

Spleen, lung and thymus were collected from each mouse and stored in RNAlater ${ }^{\circledR}$ (Ambion, USA) at $-80{ }^{\circ} \mathrm{C}$ before use. Organs were homogenized in Trizol ${ }^{\circledR}$ reagent (Life Technologies, USA) using a Tissue Lyzer homogenizer (Qiagen) following the manufacturer's protocol. Briefly, after Trizol reagent addition and homogenization, chloroform was added. The sample was centrifuged and the aqueous phase was recovered. RNA was precipitated from the aqueous phase with 2-propanol, washed with 75\% ethanol, and resuspended in sterile water. RNA concentration and purity were estimated spectrophotometrically based on absorbance at 260 and $280 \mathrm{~nm}$. First-strand cDNA was synthesized from $0.5 \mu \mathrm{g}$ of total RNA, which was reversely transcribed by using superscript III reverse transcriptase (Life Technologies, USA) and oligo (dT) as a primer.

\section{Analysis of cytokine gene expression and transcriptional regulation}

In order to monitor pro-inflammatory cytokines (IL 1- $\beta$, IL 6, IL 12p40, IFN $\gamma$ and TNF) transcript levels in organs (spleen, lung and thymus) of IFNAR(-/-) mice infected with a lethal dose of BTV-4 were quantified by RT-qPCR (ECO ${ }^{\text {TM }}$ Real-Time PCR System, Illumina ${ }^{\circledR}$, San Diego, California, U.S.). PCR experiments were carried out using the first-strand cDNAs as templates with specific primer pairs (Table 2). Target gene copy numbers were normalized using actin gene as a control, also amplified by RT-PCR. RT-qPCR was performed on an Illumina ${ }^{\circledR}$ ECO $^{\mathrm{TM}}$ thermal cycler (San Diego, California, U.S.), using SsoFast ${ }^{\mathrm{TM}}$ EvaGreen ${ }^{\circledR}$ Supermix (Bio-RadINK, Hercules, California, US) in $10-\mu \mathrm{L}$ reaction volumes comprising $1 \mu \mathrm{L}$ of cDNA template, $5 \mu \mathrm{L}$ of $2 x$ SsoFast ${ }^{\mathrm{TM}}$ mixture (with EvaGreen Dye), $1 \mu \mathrm{L}$ of primer $\operatorname{mix}\left(5 \mu \mathrm{M} /\right.$ each), and $3 \mu \mathrm{L} \mathrm{ddH}_{2} \mathrm{O}$. PCR conditions were as follows: initial denaturation at $95^{\circ} \mathrm{C}$ for $30 \mathrm{~s}$ followed by 40 cycles of $95^{\circ} \mathrm{C}$ for $5 \mathrm{~s}$, $60^{\circ} \mathrm{C}$ for $10 \mathrm{~s}$ and $60^{\circ} \mathrm{C}$ for $10 \mathrm{~s}$. After PCR, a melting curve analysis was performed by increasing the temperature from $60^{\circ} \mathrm{C}$ to $95^{\circ} \mathrm{C}$, with a temperature transition of $0.5^{\circ} \mathrm{C} / \mathrm{s}$. Each gene sample was run in duplicate for both infected and negative controls. No template controls were used in all analyses. The software used to analyze the data was EcoStudy ${ }^{\circledR}$. A dissociation curve was generated for each sample after completion of amplification and analyzed compared with the negative controls. The comparative CT (2- $\left.{ }^{\Delta \Delta} \mathrm{CT}\right)$ method was used to analyze variations in gene expression in terms of relative fold differences between the experimental (BTV infected) and calibrator (un-infected control) samples [28]. For relative quantification, the amount of target was normalized to an endogenous reference (actin, housekeeping gene) and the calibrator $2-{ }^{\Delta} \Lambda \mathrm{CT}$ formula was used: where $\Delta_{\Delta} \mathrm{CT}=\Delta \mathrm{CT}$ (sample) - ${ }^{\Delta} \mathrm{CT}$ (calibrator), the CT value indicated fractional cycle number at which the amount of amplified target reached the fixed threshold, and $\triangle \mathrm{CT}$ represented CT of the target gene subtracted from CT of the housekeeping gene. The mean $\mathrm{CT}$ values of duplicate samples of test and control mice were used for analysis. Results were presented as means \pm standard error (SE) of data from duplicate replicates.

Table 1. Primary antibodies and immunohistochemical procedures used in the histopathological studies.

\begin{tabular}{|c|c|c|c|c|}
\hline Primary antibody & Type & Antigen retrieval method & Working dilution & Incubation parameters \\
\hline CD3 (IS503, Dako) & Rabbit polyclonal & $\begin{array}{l}\text { Heating under pressure in } 10 \mathrm{mM} \text { Tris-EDTA buffer } \\
\text { (pH 9), } 15 \mathrm{~min}\end{array}$ & $1: 600$ & $2 \mathrm{~h}$ at RT \\
\hline iNOS (AHP477, Serotec) & Rabbit polyclonal & None & 1:3000 & $2 \mathrm{~h}$ at RT \\
\hline MAC387 (MS-148-R7, Neomarkers) & Mouse monoclonal & Proteinase $\mathrm{K}, 1: 500$ / $15 \mathrm{~min}$ & RTU & $2 \mathrm{~h}$ at RT \\
\hline Active Caspase-3 (G7481, Promega) & Rabbit polyclonal & $\begin{array}{l}\text { Heating under pressure in } 1 \mathrm{mM} \text { EDTA buffer ( } \mathrm{pH} 8) \text {, } \\
2 \mathrm{~min}\end{array}$ & $1: 500$ & $2 \mathrm{~h}$ at RT \\
\hline CD79a (IR621, Dako) & Mouse monoclonal & $\begin{array}{l}\text { Heating under pressure in target retrieval solution } \\
\text { high } \mathrm{pH}(\text { Dako), } 15 \mathrm{~min}\end{array}$ & RTU & $2 \mathrm{~h}$ at $\mathrm{RT}$ \\
\hline
\end{tabular}


Table 2. Primers used to analyze cytokine gene expression by RT-qPCR.

\begin{tabular}{|c|c|c|c|c|c|c|}
\hline gene & Fwd PRIMER seq (length) & Rev PRIMER seq (length) & $\begin{array}{l}\text { Length } \\
\text { product } \\
(\mathrm{pb})\end{array}$ & $\begin{array}{l}\text { Anneal } \\
\text { temperature } \\
\left({ }^{\circ} \mathrm{C}\right)\end{array}$ & $\begin{array}{l}\text { Primer } \\
\text { concentration } \\
(\mu \mathrm{M})\end{array}$ & $\begin{array}{l}\text { Product } \\
\text { Tm } \\
\left({ }^{\circ} \mathrm{C}\right)\end{array}$ \\
\hline Actin & GACGATGCTCCCCGGGCTGTATTC (24) & TCTCTTGCTCTGGGCCTCGTCACC (24) & 117 & 60 & 5 & 87 \\
\hline$I L-1-\beta$ & CAACCAACAAGTGATATTCTCCATG (25) & GATCCACACTCTCCAGCTGCA (21) & 152 & 60 & 5 & 83 \\
\hline$I L-6$ & ACCACGGCCTTCCCTACTTCAC (22) & TCСТCATTTCCACGATTTCCCAG (23) & 134 & 60 & 5 & 81 \\
\hline$I L-12 p 40$ & ACAGCACCAGCTTCTTCATCA (21) & TCTTCAAAGGCTTCATCTGCA (21) & 75 & 60 & 5 & 82 \\
\hline IFN $\gamma$ & GCGTCATTGAATCACACC (18) & GGACCTGTGGGTTGTTGACC (20) & 105 & 60 & 5 & 81 \\
\hline TNFa & AGCCCACGTCGTAGCAAACCAC (22) & ATCGGCTGGCACCACTAGTTGGT (23) & 121 & 60 & 5 & 88 \\
\hline
\end{tabular}

\section{Results}

\section{Susceptibility of IFNAR(-/-) mice to BTV-4 Morocco strain}

To determine the susceptibility of IFNAR(-/-) mice to BTV-4(M), animals were inoculated subcutaneously with ten-fold serial dilutions of BTV-4(M). At a low infection dose $\left(10^{2} \mathrm{pfu} /\right.$ mice $)$ IFNAR(-/-) mice were susceptible to BTV-4(M) infection, showing disease clinical signs characterized by ruffled hair, ocular discharges, reduced activity, and apathy starting at 48 h.p.i. Disease progression led to animal death and $100 \%$ of the infected animals died at 5 d.p.i. Similar results were observed with a dose of $10^{3} \mathrm{pfu} /$ mice. Higher infection dose of $10^{4}$ pfu/mice killed $100 \%$ of the animals at 72 h.p.i. and the appearance of clinical signs occurred at 24 h.p.i. (Fig. 1).

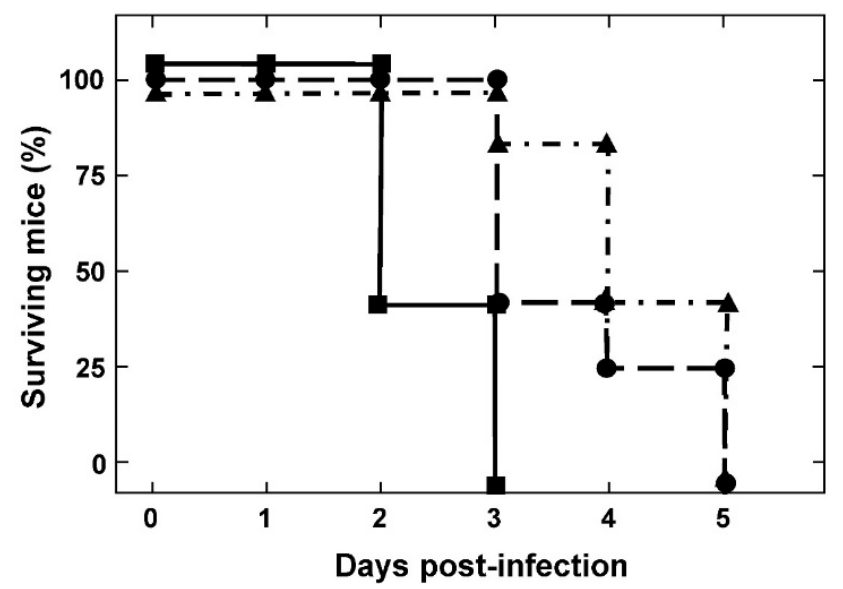

Figure 1. Susceptibility of adult mice to BTV-4 Morocco strain infection. IFNAR(-/-) mice (8 weeks old, 5 mice per group) were subcutaneously inoculated with 10 -fold dilutions of BTV-4. The number of PFUs inoculated is indicated on each survival group (10e2 $\mathbf{\Delta}, 10 \mathrm{e} 3 \bullet, 10 \mathrm{e} 4 \mathrm{~m})$. The mice were observed every $12 \mathrm{~h}$ for 5 days.

\section{Blood parameters and viraemia in BTV infected IFNAR(-/-) mice.}

Viral spread and viraemia were determined in blood and tissue samples of mice infected with $10^{3}$ $\mathrm{pfu} /$ mice by RT-qPCR. Viraemia was detected at 24 h.p.i and the presence of virus in blood was increased thereafter until animal death. The first tissue to be reached by the virus was the spleen where BTV genome was detected as early as 24 h.p.i. (Ct: $30.49 \pm 1.05$ ) (Table 3). By 48 h.p.i. viral genomes and BTV protein (figure S1) were also detected in the lung, thymus, and inguinal lymph nodes. The presence of BTV genomes increased thereafter until the death of the animal. No infectious virus was detected in the liver, brain, heart, tongue, skin, and testicles at any time points examined (data not shown).

Changes in haematology were determined after infection of IFNAR(-/-) mice with $10^{3} \mathrm{pfu} /$ mice (Fig. 2). BTV infection resulted in a significant decrease in the total white blood cell counts by 72 h.p.i (from $9.6 \times 10^{6}$ to $2.54 \times 10^{6}$ cells $/ \mathrm{ml}$ ) highlighted by a 8 -fold drop in the absolute lymphocyte counts as well as a $60 \%$ reduction in the percentage of lymphocytes. In addition, a dramatic reduction in the absolute monocyte count was detected in the infected mice. In contrast, an increase in the neutrophil percentage and in their absolute count was observed due to the BTV infection. Platelet counts also decreased in BTV-infected mice by up to 2-fold over the course of the infection. Thrombocytopenia is indicative of coagulation disorders and may partially explain the haemorrhages observed in the spleen, lung and liver of BTV infected mice (figure S2).

Table 3. Detection of BTV-4(M) in blood and tissues of infected IFNAR(-/-) mice after challenge by RT-qPCR_S5.

\begin{tabular}{llll}
\hline & 24 h.p.i. & 48 h.p.i. & 72 h.p.i. \\
\hline Blood & $29.07 \pm 1.02$ & $25.05 \pm 0.23$ & $23.78 \pm 1.1$ \\
Thymus & Neg. & $29.17 \pm 21.54$ & $21.71 \pm 0.92$ \\
Lung & $36.69 \pm 1.23$ & $22.84 \pm 1.1$ & $20.77 \pm 3.31$ \\
Spleen & $30.49 \pm 1.05$ & $22.88 \pm 2.32$ & $18.89 \pm 1.37$ \\
Lymph node (inguinal) & N.D. & $25.82 \pm 1.25$ & $22.37 \pm 2.64$ \\
\hline \multicolumn{4}{l}{ Results expressed as Ct and transferred to negative (neg.) according to the cut-off } \\
Ct $\geq 38$ described by Toussaint et al. (2007).
\end{tabular}


A
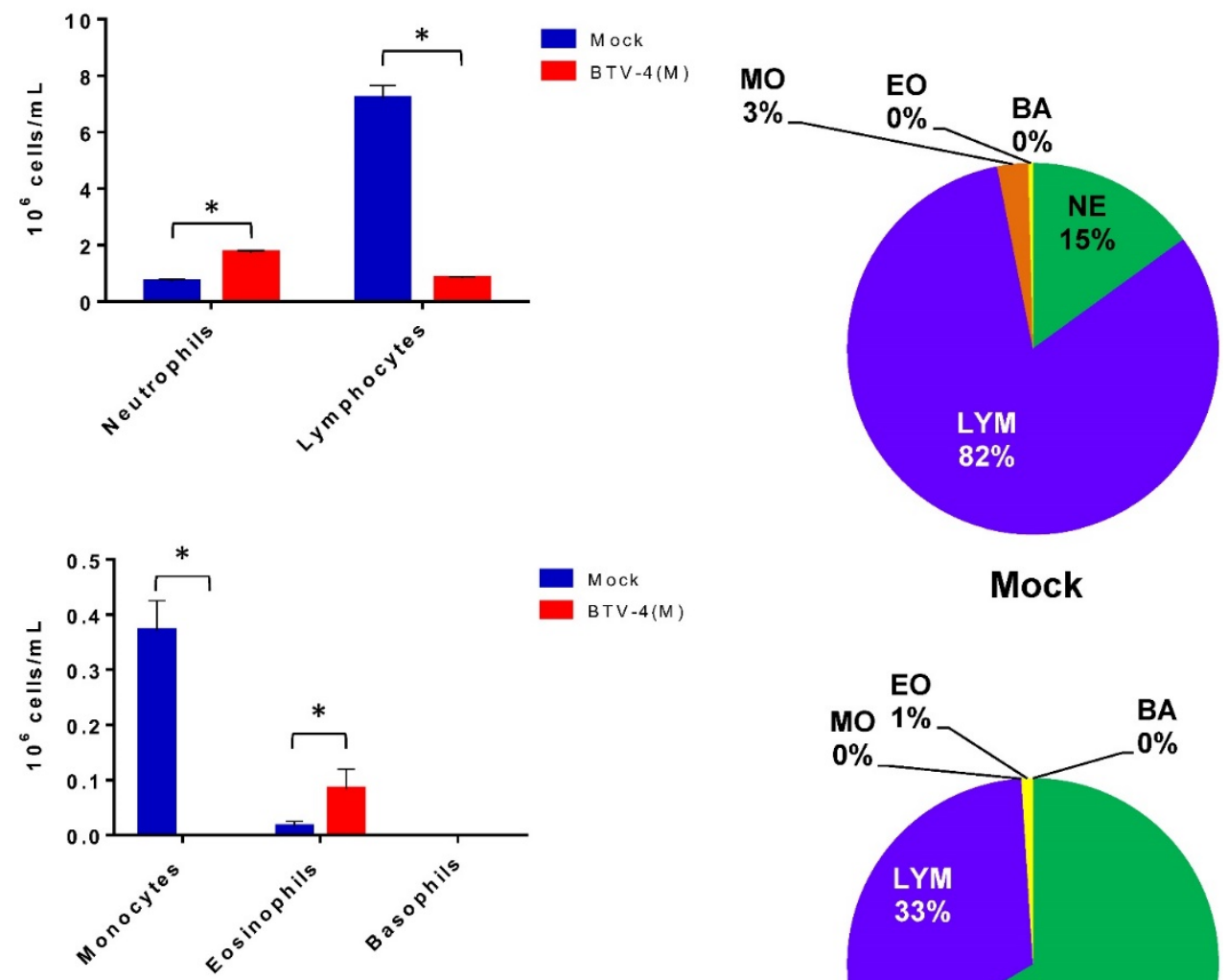

Mock

BTV $-4(M)$

Mock
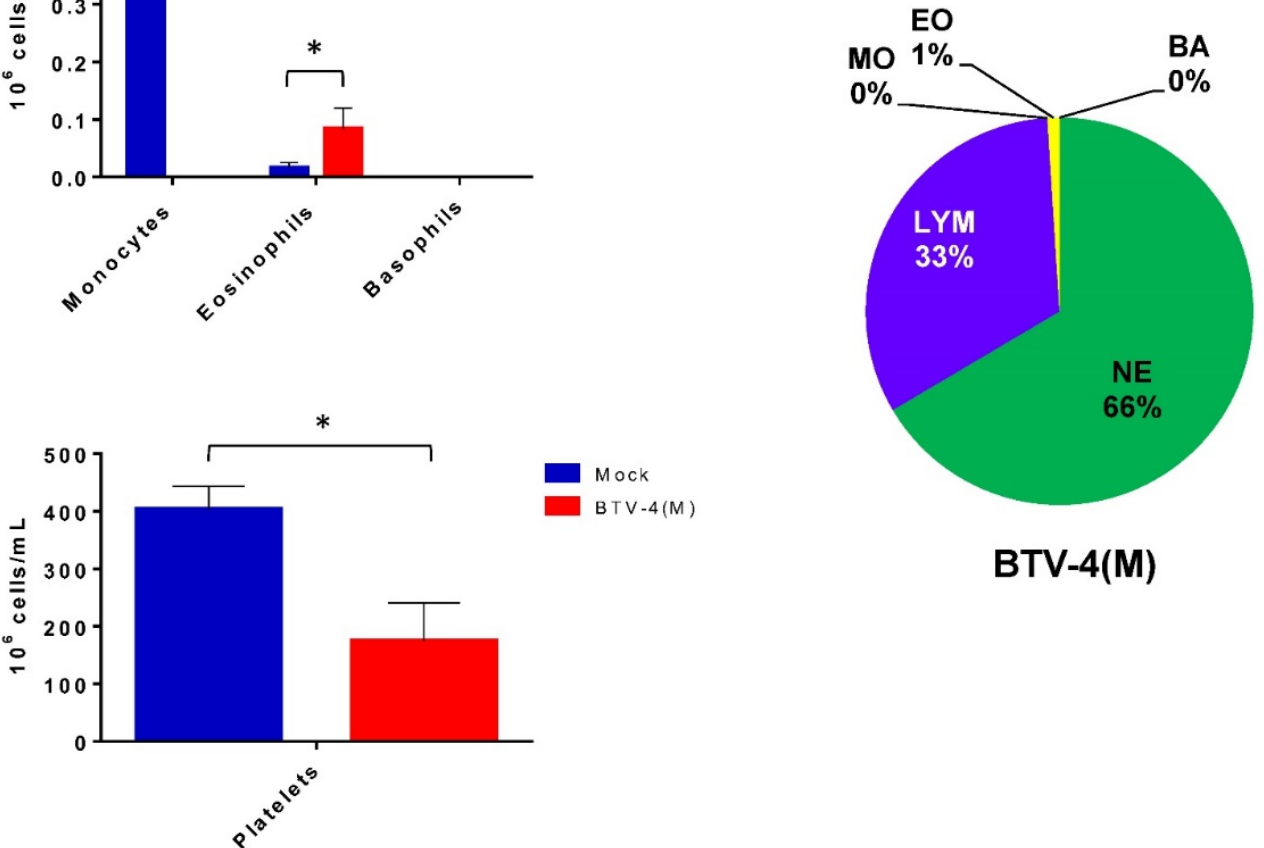

BTV-4(M)

Figure 2. Blood parameters in IFNAR(-/-) mice infected with BTV-4 Morocco strain. Mice were infected subcutaneously with 1033 PFU of BTV-4 (MOR2009/09) per mouse. Whole blood was collected at 72 h.p.i. and the following parameters were analyzed: lymphocytes, monocytes, neutrophils, basophils, eosinophils, and platelets. (A), Cell count. (B), Cell percentage. The results represent the average of 5 mice \pm SD. Asterisks represent significant difference between samples, calculated by Man-Whitney non parametric test $(p \leq 0.01)$.

\section{Histopathologic changes in organs of BTV infected IFNAR(-/-) mice}

In order to study the pathological effects of the infection in the organs where BTV-4 replicates, histological analysis were performed on several organs extracted from BTV infected and uninfected IFNAR(-/-) mice at 72 h.p.i. Light microscopy on lungs from infected mice revealed diffuse interstitial pneumonia characterized by hyperaemia, thickening of alveolar septa with infiltrates composed by mononuclear cells and scarce neutrophils, and the presence of oedema and leak of red blood cells into the alveolar spaces (Fig. 3). The spleen of infected mice showed severe white pulp lymphocytolisis and lymphoid depletion, as well as neutrophilic infiltrates in the margin between the red and white pulp (Fig. 3). As splenic lesions progressed, the white pulp was reduced to small foci of periarteriolar lymphoid tissue, surrounded by abundant apoptotic debris, neutrophils and siderocytes (Fig. 3). Lymphoid depletion was also observed in the thymus, where the typical structure of medulla-cortex was 
indistinguishable and large areas of the parenchyma were replaced by necrotic tissue (Fig.3).

By means of immunohistochemistry, a dramatically decrease of immunoreactivity against CD3 antibody (a T cell marker) was observed in the spleen and thymus of the infected mice, with foci of CD3+ cells in periarteriolar areas of the spleen and few positive cells scattered through the thymus parenchyma (Fig. 4). Similarly, a lower number of cells immunoreactive against CD79 (a B cell marker), restricted to the remnants of the white pulp, was observed in the spleen from infected mice compared to control. Besides, scarce small foci of CD79+ cells were found in the lungs, close to pneumonic areas (Fig. 5). On the other hand, a clear increase in immunoreactivity against MAC387 and iNOS antibodies was detected in the spleen and thymus of the infected mice. Positive cells to both antibodies were diffusely observed in the thymus parenchyma, whereas in the spleen, MAC387+ cells were mainly

\section{Mock}

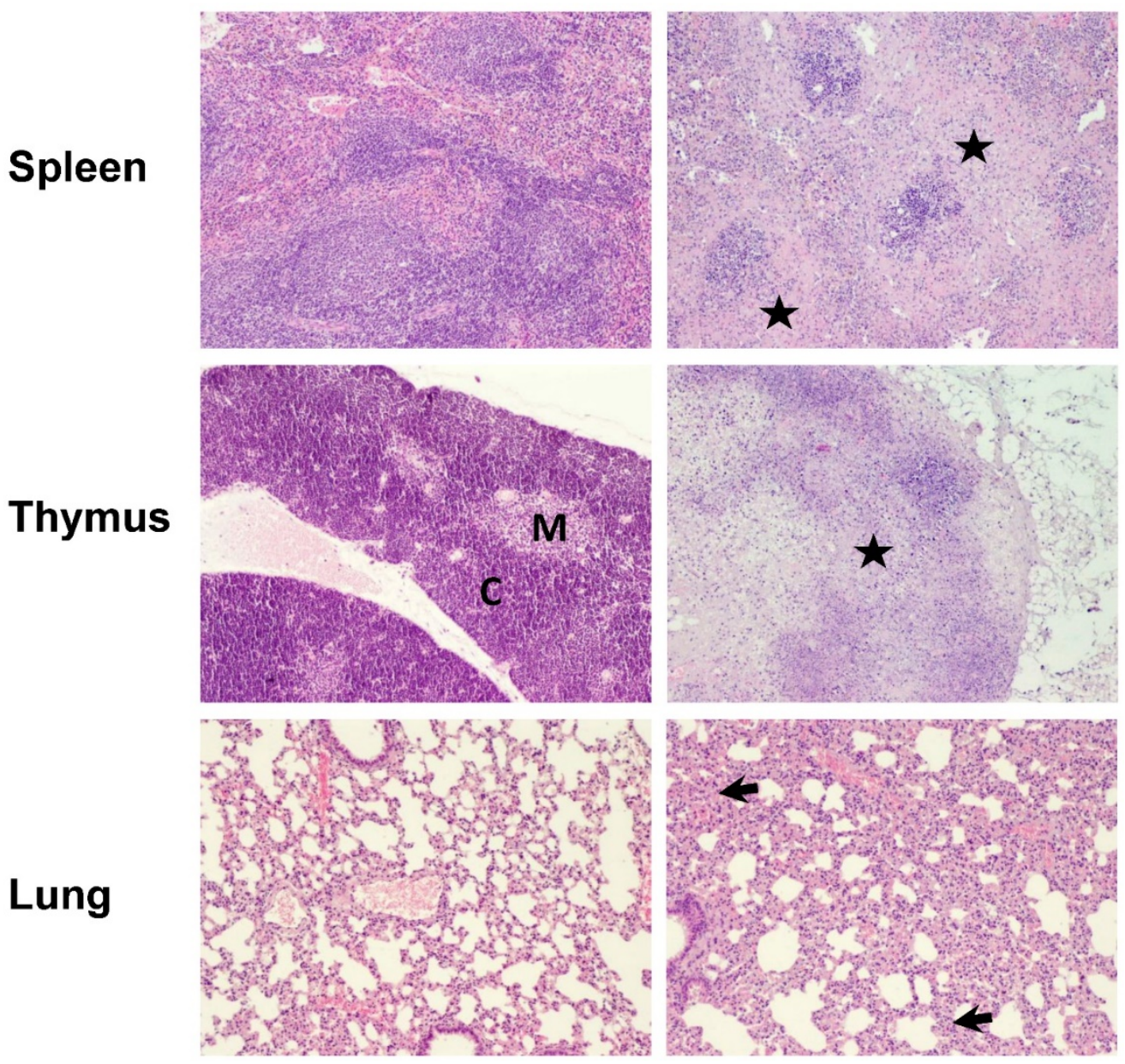

Figure 3. Comparative photomicrograph of tissue sections from BTV-4- infected and control animals. H\&E, 100X. IFNAR(-/-) mice $(n=3)$ were infected subcutaneosuly with $10^{3}$ PFU of BTV-4. Representative pictures of tissues from the spleen, thymus, and lung collected at 72 h.p.i. and stained with hematoxylin and eosin, are shown. Extensive necrosis and lymphoid depletion, mainly located in the marginal zone bordering the white pulp (asterisk), was detected in the spleen from BTV-infected specimens, as well as a population of neutrophils and macrophages invading necrotic tissue. The thymus of BTV-infected animals showed extensive necrosis and lymphoid depletion (asterisk), with loss of the boundaries between the medulla (M) and the cortex (C). In the lungs of BTV-infected animals a diffuse interstitial pneumonia was encountered, showing multifocal atelectasis and increased septum size (arrows), with infiltration of mononuclear cells and scarce neutrophils. 
Mock

Spleen

Thymus

Lung
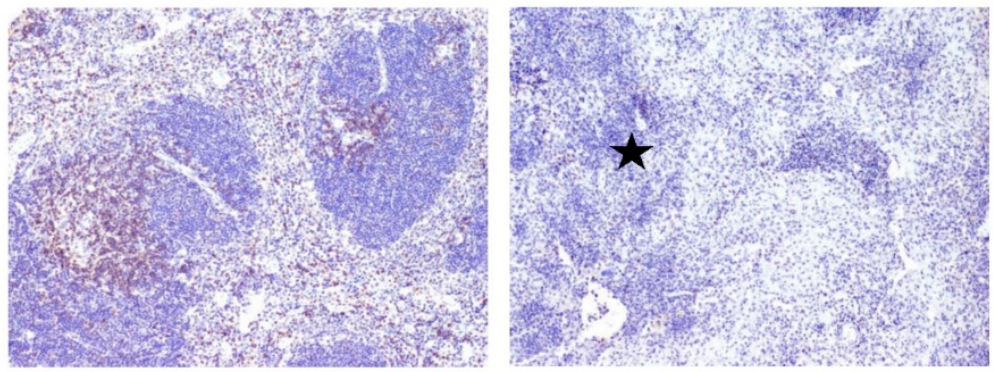

BTV-4
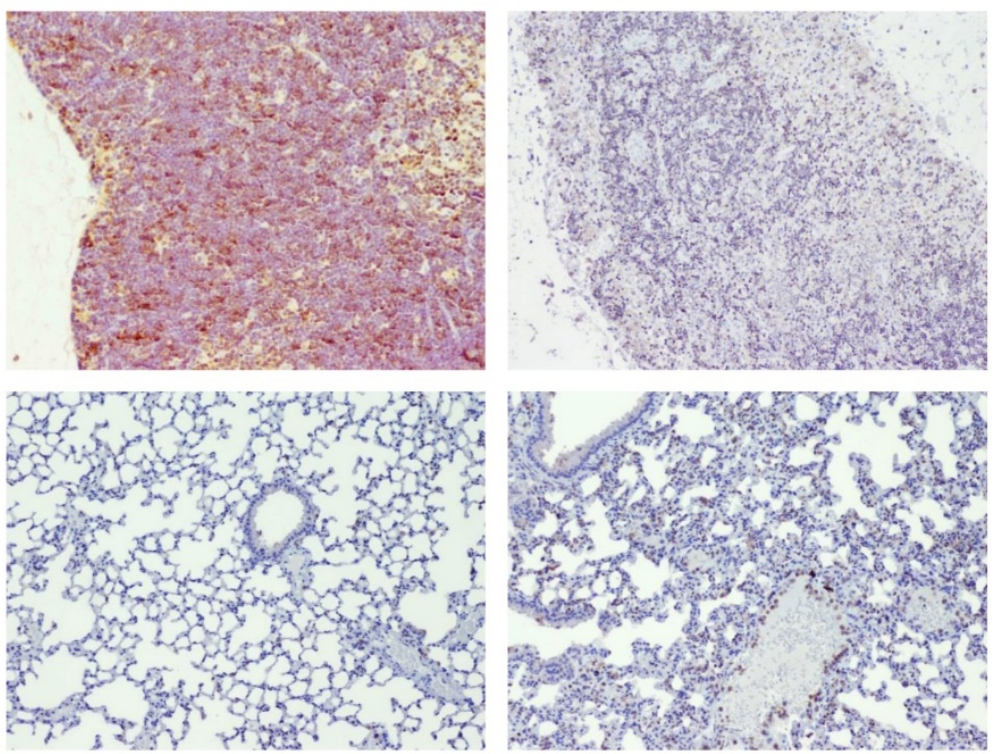

Figure 4. Representative photomicrographs showing the difference in the number/distribution of CD3 positive cells in spleen, thymus and lung, between BTV-infected and Mock mice. IHC against CD3, 100X. A significant decrease in the number of CD3+ cells was observed in spleen and thymus from infected animals. Populations of CD3+ cell were restricted to periarteriolar areas in spleen (asterisk). A mild increase in the number of CD3+ cells, dispersed throughout the pulmonary parenchyma, was also observed.

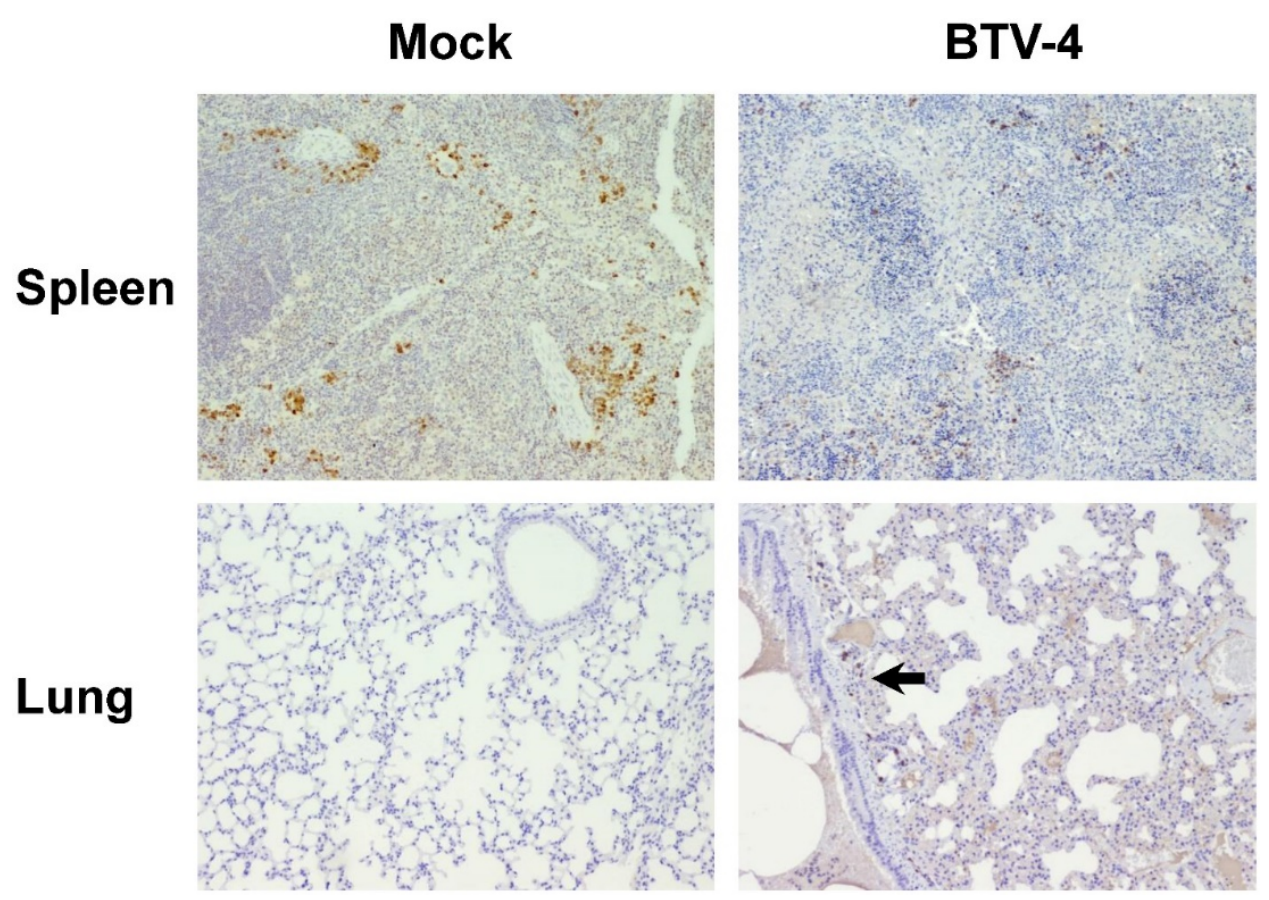

Figure 5. Representative photomicrographs of immunohistochemical technique against CD79 antibody in spleen and lungs from BTV-4-infected and Mock animals. IHC against CD79 antibody, 100X. Immunoreactivity against CD79 was mainly present close to the remnants of the white pulp in the spleen of infected mice, being diminished in BTV-infected mice compared to controls. A small cluster of CD79+ cells (arrow) was observed in lungs of BTV-infected animal, within a pneumonic focus. 


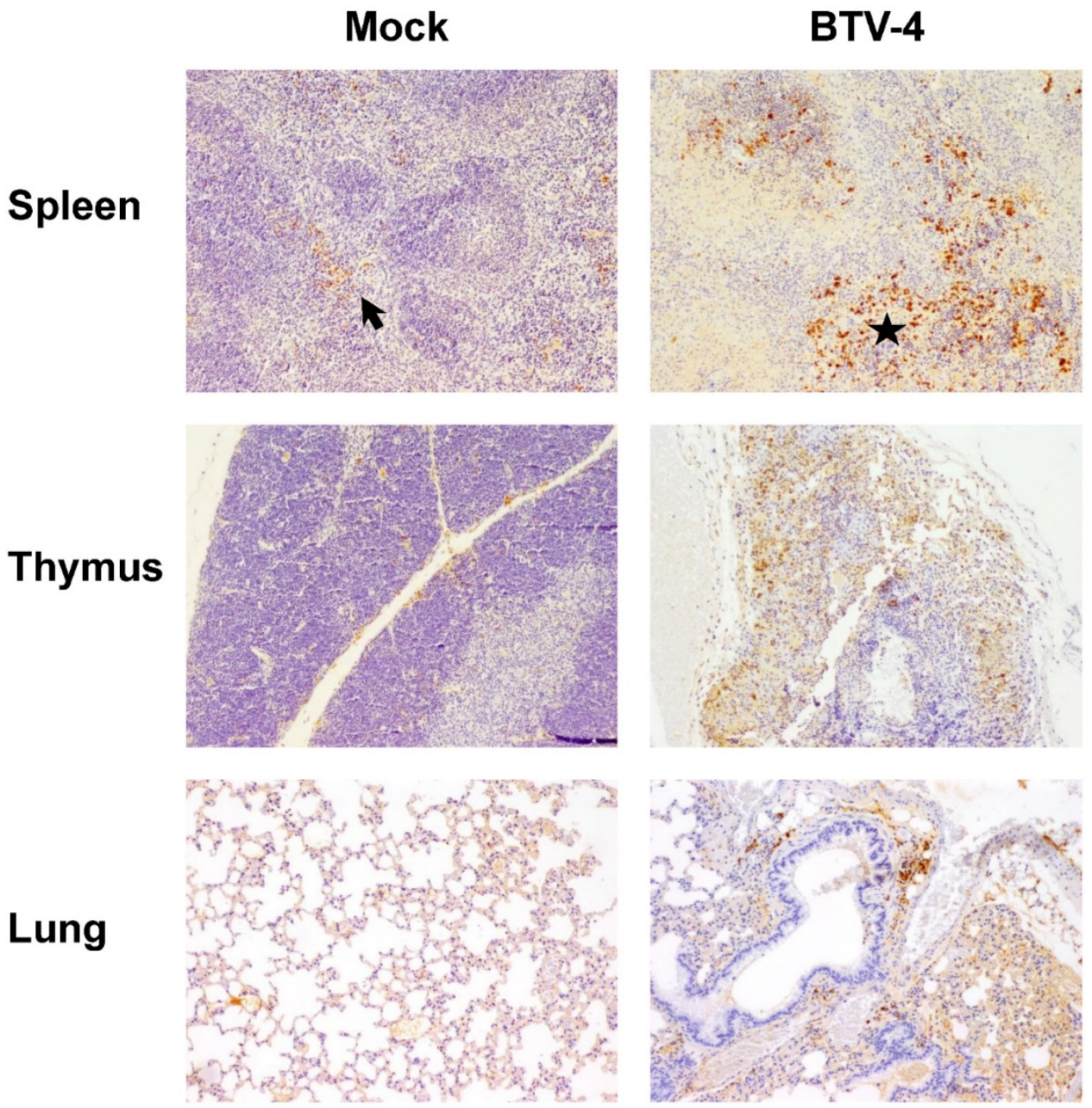

Figure 6. Representative micrographs of immunohistochemical technique against MAC387 antibody in spleen, thymus and lungs from BTV-4-infected and Mock animals. IHC against MAC387 antibody, 100X. Positivity against MAC387 antibody in Mock-infected mice was mainly found in medullar sinuses (arrow), whereas in infected individuals the number of MAC387+ cells was increased, being scattered throughout the white pulp (asterisk). Immunoreactivity against MAC387 antibody was higher in the thymus from BTV-4-infected mice when compared with control animals, mainly in peripheral areas of the thymic parenchyma. Few small foci of MAC387+ cells (arrow) present in lung of BTV-infected animal, close to a bronchiole.

\section{BTV infection causes strong proinflammatory immune responses in IFNAR(-I-) mice}

To further investigate the pathogenesis of BTV, we evaluated the induction of pro-inflammatory cytokines in the tissues where BTV replicates by measuring transcript levels. IFNAR(-/-) mice developed strong pro-inflammatory immune responses following BTV-4 infection, as demonstrated by a significant increase in mRNA of IL-1 $\beta$, IL-6, IL-12p40, IFN- $\gamma$, and TNF in the lung, and specially in the thymus and spleen (Fig. 9). The upregulation of pro-inflammatory cytokine mRNA correlated with virus replication, iNOS induction and the presence of monocytes/macrophages in these tissues.

\section{Discussion}

Ruminants are the natural host species in which BT disease occurs and are therefore the preferred animals to conduct experimental infection studies.
However, infection studies using ruminants are expensive and time consuming and a limited number of animals are generally included [29]. Inbred IFNAR(-/-) mice are far easier and cheaper to work with. A tremendous advantage of this mouse model is the availability of a wide variety of reagents that can be used to study many aspects of the immune response to the virus. Although extrapolation of findings in mice to ruminants must be done with care due to differences in the biology between mouse and ruminant species, IFNAR(-/-) mice have been used as an animal model to study BTV transmission, pathogenesis, virulence, and protective efficacy of inactivated and new recombinant marker BTV vaccines [19-26].

The susceptibility of IFNAR(-/-) mice to BTV infection has been previously characterized in our laboratory for strains of BTV-1, BTV-8, and BTV-4 [20, $30,31]$. For the present work we have used a strain of BTV-4 (MOR2009/09) isolated from sheep blood by 
using a culicoides cell line (KC cells) that has not been passed through mammalian cell lines. The clinical disease produced in IFNAR(-/-) mice infected with BTV-4(M) includes high viraemia and viral tissue titers in spleen, lung and thymus, which were detectable starting at 2 d.p.i. until death. Thus, an increased percentage of neutrophils and profound loss of lymphocytes, monocytes and platelets was observed in the blood after BTV infection. These results reproduce the data reported in experimental infections of sheep with BTV-23 and white-tailed deer with BTV-17 where marked thrombocytopenia, lymphopenia, and neutrophilia were observed [13, 32, 33]. Lymphoid depletion and neutrophilic infiltrates were observed in H\&E stained sections of spleen and thymus of BTV-4(M) infected IFNAR(-/-) mice. Lymphoid depletion was confirmed by IHC, showing moderate decreased immunopositivity against CD3 in the thymus, and scarce immunoreactivity against CD3 and CD79 in the remains of the white pulp of the spleen. The reduction in CD3 and CD79 reactivity in lymphoid tissues of BTV infected mice indicates lymphopenia, as it has been described commonly in sheep during infections with several BTV serotypes. One of the mechanisms proposed for lymphoid depletion includes apoptosis [34]. Alternatively, BTV replication in lymphocytes, monocytes/macrophages and/or dendritic cells could result in cellular injury [35]. Lymphoid depletion could produce immunosupression and predisposition to secondary microbial infections as it has been observed in experimental infections of sheep with BTV. A positive signal specific of BTV has been observed in the lymph nodes, spleen, and thymus of BTV infected mice [31]. In addition, a clear increase of active caspase- 3 was detected in the same tissues after infection indicating that both mechanisms can be also implicated in the lymphoid depletion observed in IFNAR(-/-) mice.

\section{Mock}

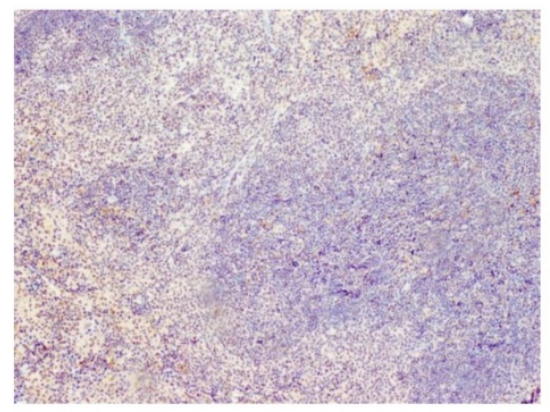

Spleen

\section{Thymus}
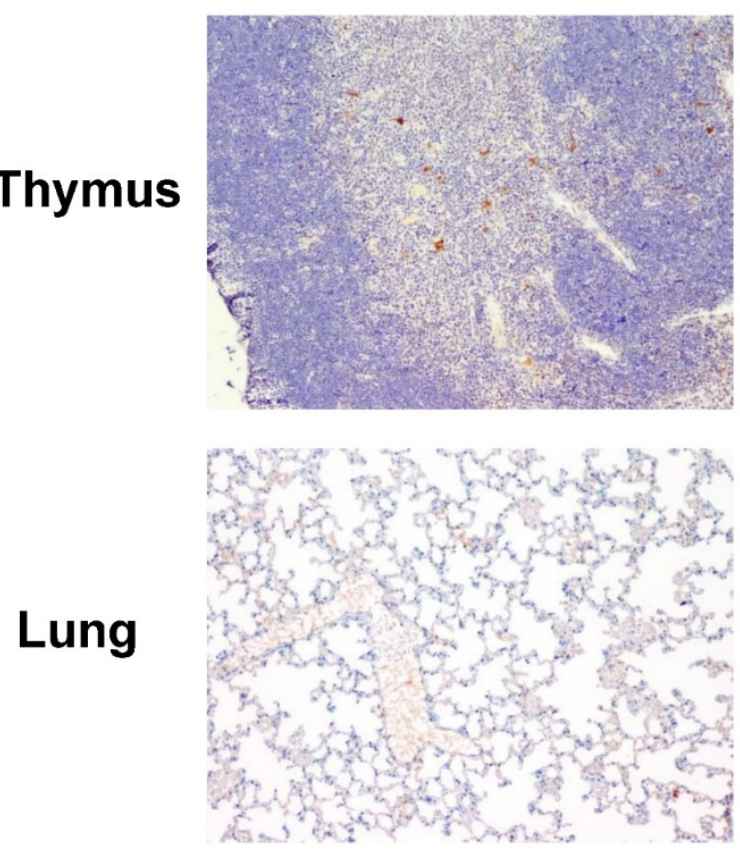

\section{BTV-4}
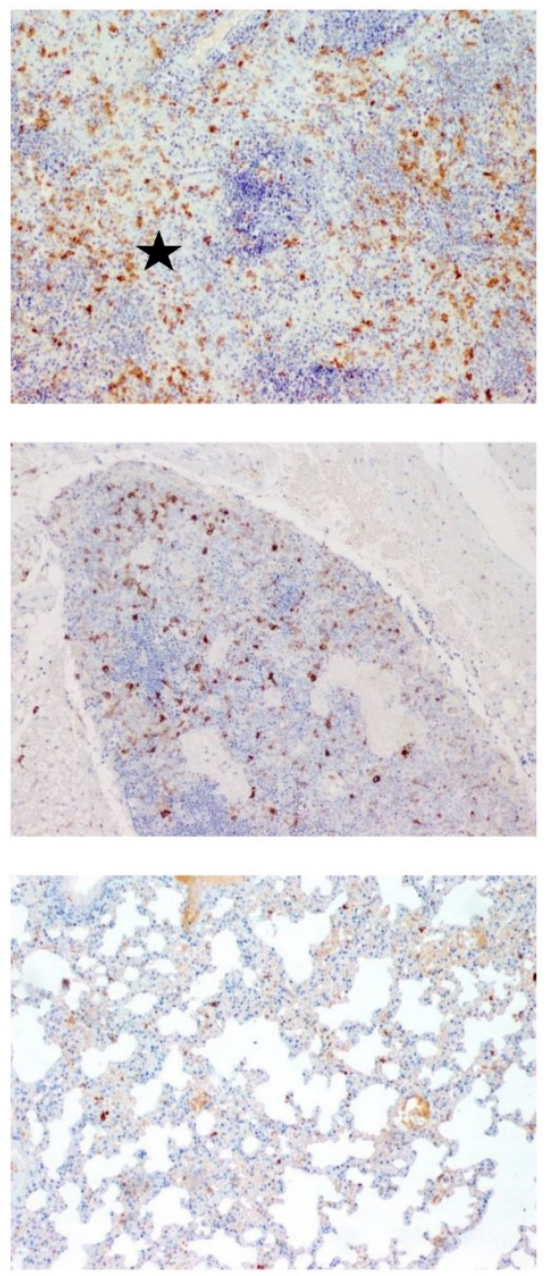

Figure 7. Representative micrographs of immunohistochemical technique against iNOS antibody in spleen, thymus and lungs from BTV-4-infected and Mock animals. IHC against iNOS antibody, 100X. The number of iNOS+ cells was highly increased in spleen from BTV-infected animals and these cells were mainly located in necrotic areas surrounding the white pulp (asterisk). In the thymus of infected mice, immunoreactivity against iNOS antibody was higher than mock-infected individuals and was randomly distributed throughout the parenchyma. A few number of iNOS+ cells was present in the inflammatory infiltrate of the lung of infected mice. 


\section{Mock}
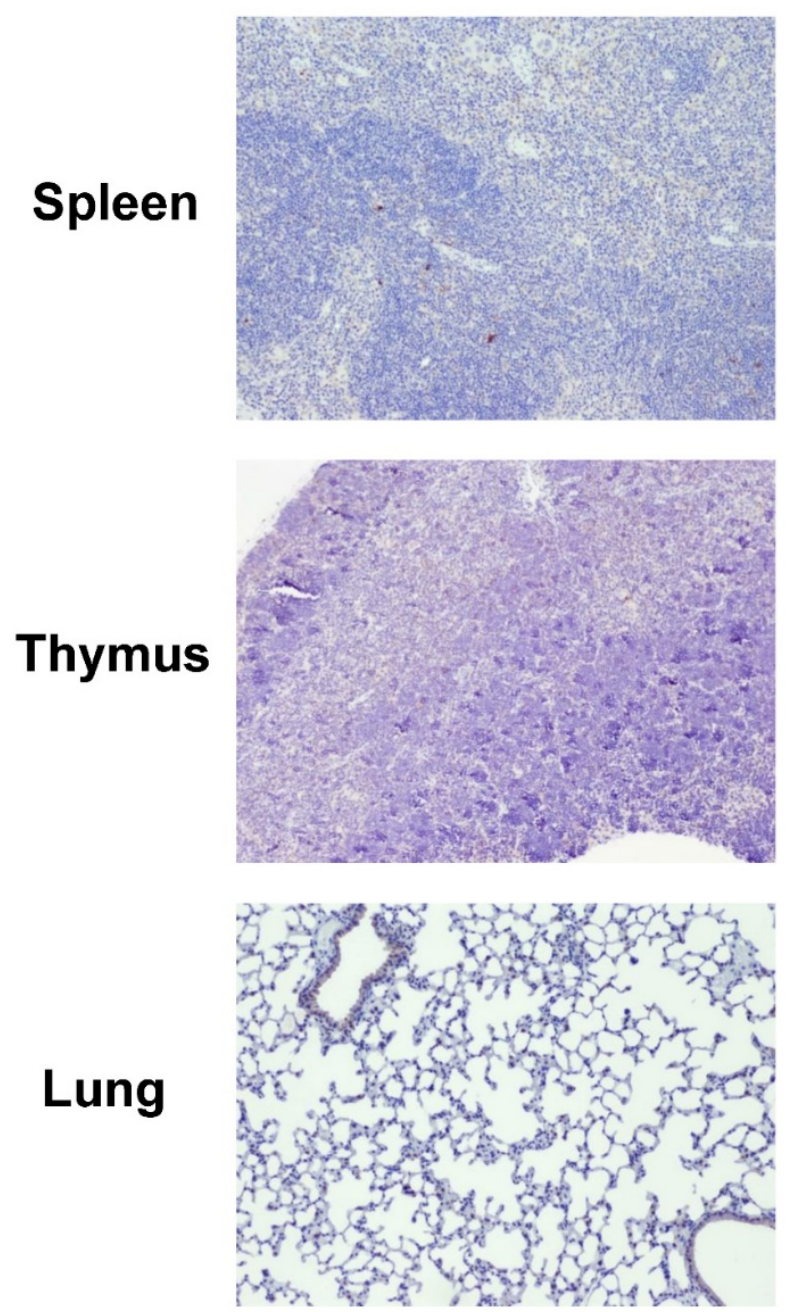

\section{BTV-4}
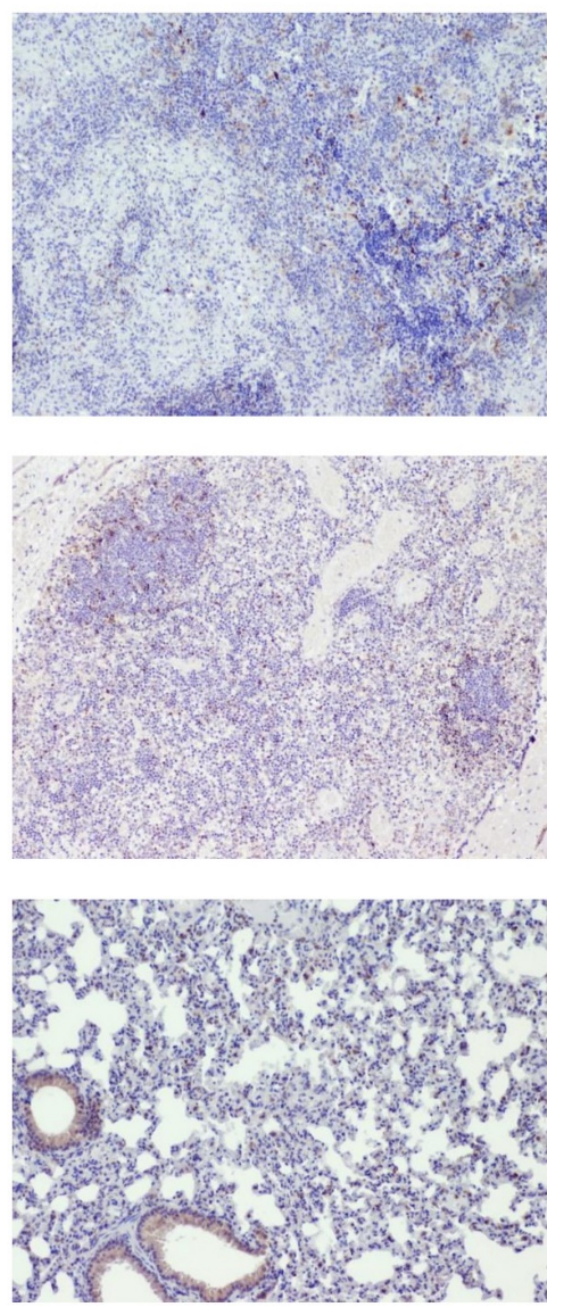

Figure 8. Representative micrographs of immunohistochemical technique against active caspase-3 antibody in spleen, thymus and lung from BTV-4-infected and Mock animals. IHC against caspase-3 antibody, 100X. The number of active caspase- 3 cells was moderately increased in spleen, thymus, and lung from BTV-infected animals, concurring with the apoptotic debris.

In contrast, an increase in MAC387 immunostaining was observed mainly in spleen and thymus and, to a lesser extent, in lung of infected mice. The morphology of cells positive to MAC387 antibody was compatible with either monocytes/macrophages. The accumulation of macrophages in these three tissues has been previously reported in BTV infected ruminants $[9,36]$ and it has been suggested that macrophages are positioned in the infected tissues to capture, internalize and process BTV antigens.

Previously it was reported from both in vivo and in vitro studies that BTV- infected mononuclear leukocytes (dendritic cells, macrophages, monocytes and some lymphocytes) secrete numerous pro-inflammatory cytokines, including IFN- $\alpha$, IFN- $\gamma$, IL-12, TNF, IL-1 $\beta$ and IL-8 [8, 14, 37-39]. Induction of a balanced antiviral and pro-inflammatory response is crucial to control viral replication and activate optimal adaptive immune responses. Although such response is required for viral clearance, depending on the type of disease, it may also damage tissues in severe cases, contributing to disease pathogenesis [40]. The endothelial injury observed in ruminants during BTV infection could be due to the direct pathogenic effect of BTV infection on endothelial cells or to a response to inflammatory mediators released by virus-infected endothelial cells and, possibly, other cell types such as monocytes/macrophages [8, 14, 18, 39]. Furthermore, in vitro BTV infections of peripheral blood mononuclear cells (PBMC) from a number of ruminant species resulted in the production of inflammatory cytokines. BTV infection of PBMC from bovine [39], sheep and goats [41] induced IL-1, 6, 8, and 10, IFN-y, TNF and iNOS, although these studies used different experimental designs and BTV serotypes, making correlations among species difficult. 


\section{thymus}

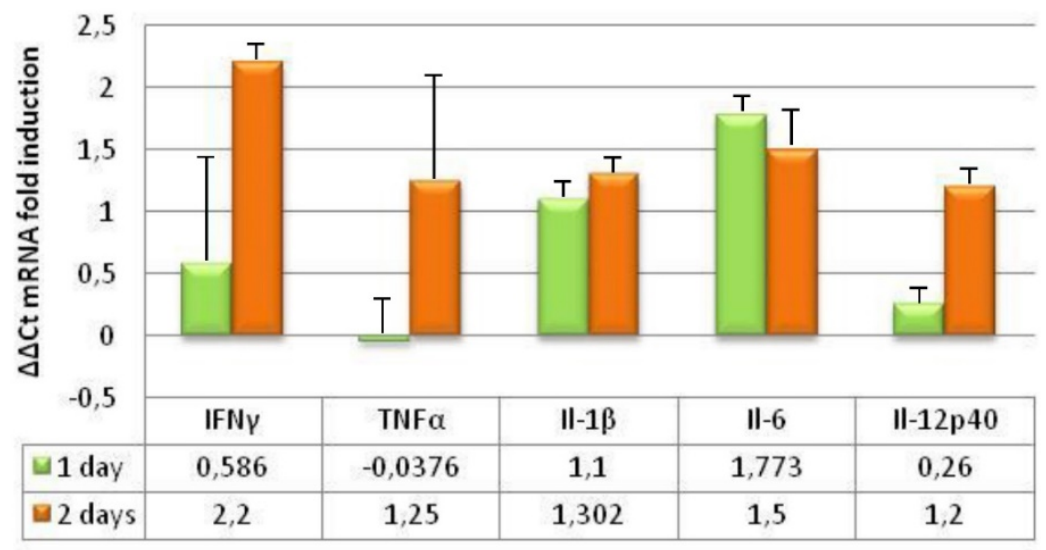

\section{lung}

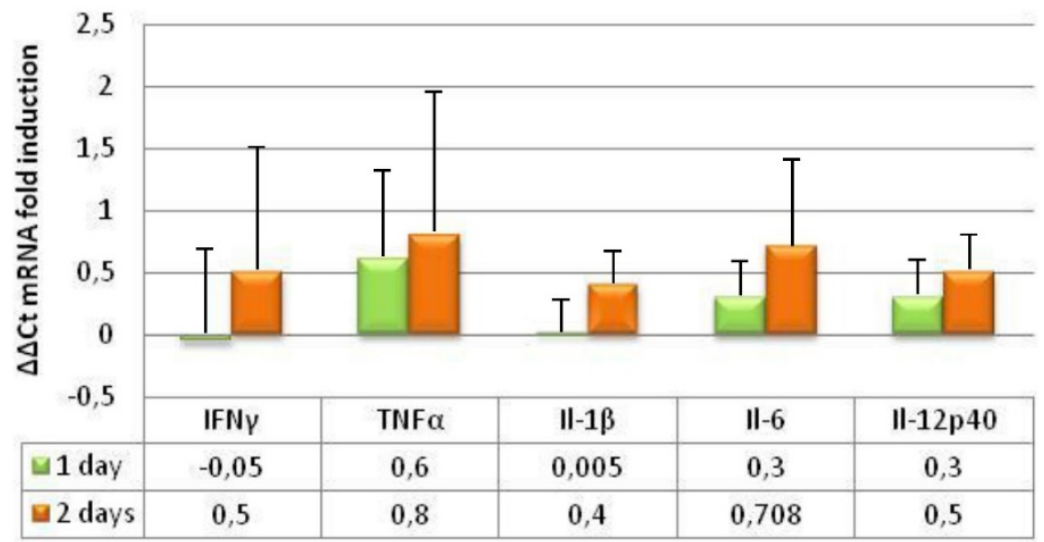

\section{spleen}

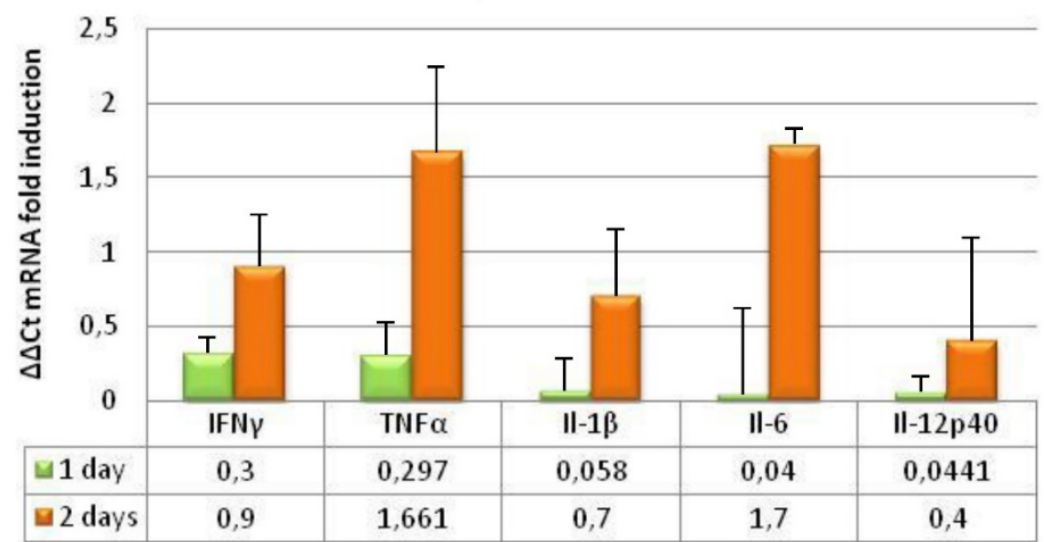

Figure 9. Proinflammatory cytokines changes in IFNAR(-/-) mice infected with BTV-4 Morocco strain. Tissue samples were collected at the indicated time points from individual IFNAR(-/-) mice (3 per time point) infected with $10^{3}$ PFU of BTV-4. Total RNA from spleen, thymus and lungs were extracted, and the expression of mRNA of proinflammatory cytokines was quantified. The expression levels of the different genes were normalized to levels in mock-infected mice. Columns represent mean values and error bars represent the SD of three independent mice per group.

To further investigate whether the presence of macrophages in spleen, thymus, and lung of BTV infected IFNAR(-/-) mice correlated with an activation of pro-inflammatory response in these tissues we evaluated the induction of pro-inflammatory cytokines in the tissues where BTV replicates by measuring transcript levels. BTV infection of IFNAR(-/-) mice resulted in increased transcription of genes encoding IL-1 $\beta$, IL-6, IL-12p40, IFN- $\gamma$, and TNF. In addition, the higher presence of 
macrophages in spleen and thymus correlated with higher induction of pro-inflammatory cytokines, tissues, which also showed higher histopathological alterations. Besides the induction of pro-inflammatory cytokines observed in serum and tissues of BTV infected ruminants, it has been also reported that BTV infection of sheep led to enhance transcription of iNOS in peripheral blood mononuclear cells and regional lymphoid organs [42]. Furthermore, in vitro studies provided evidence that cytokines and other vasoactive substances produced in macrophages potentially contributed to vascular injury in BTV-infected ruminants [39]. The IFNAR(-/-) mouse model reproduced in vivo the increase expression of iNOS in BTV-4(M) infected tissues. Positive cells to iNOS antibody were slightly augmented in lung and greatly increased in spleen and thymus of infected animals, compared to the control mice, and the morphology of cells positive to iNOS+ were compatible with both monocytes/macrophages and neutrophils. Nitric oxide is a potent anti-viral molecule to combat infection in combination with acute phase proteins and cytokines. Nevertheless, the excessive production of iNOS, and subsequent high levels of $\mathrm{NO}$ during viral infections may have negative effects, acting with other damaging oxidants to promote excessive inflammation or induce apoptosis, as it has been described in influenza virus infection [43]. As it has been described in the pathogenesis of viral hemorrhagic fevers [15, 44, 45], the overproduction of iNOS and pro-inflammatory cytokines in BTV infected tissues could contribute to the pathology of this disease-causing vasodilatation, increase of leukocyte adhesion and thrombus formation, and increase of vascular permeability of endothelial cells with subsequent tissue edema [39, 46].

BTV induces apoptosis both in cultured cells and in target tissues in vivo and one current hypothesis is that apoptosis plays a major role in the pathogenesis of BTV infection [47-49]. The spleen of BTV infected IFNAR(-/-) mice showed apoptotic debris and high presence of active caspase-3, reproducing the apoptotic effect observed in BTV infected sheep. Active-caspase-3 is an important pro-apoptotic molecule and acts as final effector in all apoptotic pathways, and it can be considered as a good marker for apoptosis [50]. It is noteworthy that the number of positive cells against active caspase- 3 is not high enough to explain the massive necrosis and lymphoid depletion that take place in spleen and thymus of BTV-infected mice. This is probably because Caspase-3 is unable to detect all apoptotic cells [51] , and necrosis also occurs in these tissues, likely due to the increased oxidative environment. The role of active caspase- 3 in BTV-induced apoptosis has been confirmed in cell lines [47] and in sheep infected with BTV-23 where apoptosis in the spleen and peripheral blood mononuclear cells (PBMC) and up-regulation of caspase-3 mRNA in PBMC were observed [34]. It has been suggested that IFN-a could mediate apoptosis activating the release of pro-inflamatory cytokines and mediating nitric oxide production from activated macrophages or endothelial cells [34]. The induction of apoptosis in the BTV infected IFNAR(-/-) mice, where the IFN-a signaling pathway is blocked, indicates that BTV infection could lead to apoptosis in an independent IFN- $\alpha$ fashion.

Ruminants are currently the best animal model to study BTV infection. Furthermore, any promising vaccine or treatment to be considered for clinical trials must be successful in ruminants. However, due to ethical, practical, and financial considerations, a murine model that reproduces pathological aspects of viral infection is a valuable tool to screen potential vaccine efficacy and to study BTV transmission, pathogenesis and virulence.

\section{Supplementary Material}

Supplementary figures.

http://www.ijbs.com/v12p1448s1.pdf

\section{Acknowledgment}

We thank Dr. Juan Anguita for stimulating discussions and critically reading the manuscript. This work was supported by grants from the Comisión Interministerial de Ciencia y Tecnología (CICYT) (AGL2011-23506 and AGL-2014- 57430-R).

\section{Competing Interests}

The authors have declared that no competing interest exists.

\section{References}

1. Maan S, Maan NS, Nomikou K, Veronesi E, Bachanek-Bankowska K, Belaganahalli $\mathrm{MN}$, et al. Complete genome characterisation of a novel 26th bluetongue virus serotype from Kuwait. PLoS One. 2011; 6: e26147.

2. Maclachlan NJ, Wilson WC, Crossley BM, Mayo CE, Jasperson DC, Breitmeyer $\mathrm{RE}$, et al. Novel serotype of bluetongue virus, western North America. Emerging infectious diseases. 2013; 19: 665-6.

3. Jenckel M, Breard E, Schulz C, Sailleau C, Viarouge C, Hoffmann B, et al. Complete coding genome sequence of putative novel bluetongue virus serotype 27. Genome Announc. 2015; 3.

4. Mellor PS, Boorman J, Baylis M. Culicoides biting midges: their role as arbovirus vectors. Annu Rev Entomol. 2000; 45: 307-40.

5. Barratt-Boyes SM, MacLachlan NJ. Pathogenesis of bluetongue virus infection of cattle. Journal of the American Veterinary Medical Association. 1995; 206: 1322-9.

6. Pini A. Study on the pathogenesis of bluetongue: replication of the virus in the organs of infected sheep. The Onderstepoort journal of veterinary research. 1976; 43: 159-64.

7. Barratt-Boyes SM, MacLachlan NJ. Dynamics of viral spread in bluetongue virus infected calves. Veterinary microbiology. 1994; 40: 361-71.

8. Hemati B, Contreras V, Urien C, Bonneau M, Takamatsu HH, Mertens PP, et al. Bluetongue virus targets conventional dendritic cells in skin lymph. J Virol. 2009; 83: 8789-99. 
9. Sanchez-Cordon PJ, Rodriguez-Sanchez B, Risalde MA, Molina V, Pedrera M, Sanchez-Vizcaino JM, et al. Immunohistochemical detection of bluetongue virus in fixed tissue. J Comp Pathol. 2010; 143: 20-8.

10. DeMaula CD, Leutenegger CM, Bonneau KR, MacLachlan NJ. The role of endothelial cell-derived inflammatory and vasoactive mediators in the pathogenesis of bluetongue. Virology. 2002; 296: 330-7.

11. McLaughlin BE, DeMaula CD, Wilson WC, Boyce WM, MacLachlan NJ. Replication of bluetongue virus and epizootic hemorrhagic disease virus in pulmonary artery endothelial cells obtained from cattle, sheep, and deer. American journal of veterinary research. 2003; 64: 860-5.

12. Whetter LE, Maclachlan NJ, Gebhard DH, Heidner HW, Moore PF, Bluetongue virus infection of bovine monocytes. The Journal of general virology. 1989; 70 ( Pt 7): 1663-76.

13. Maclachlan NJ, Drew CP, Darpel KE, Worwa G. The pathology and pathogenesis of bluetongue. J Comp Pathol. 2009; 141: 1-16.

14. Channappanavar R, Singh KP, Singh R, Umeshappa CS, Ingale SL, Pandey AB. Enhanced proinflammatory cytokine activity during experimental bluetongue virus-1 infection in Indian native sheep. Vet Immunol Immunopathol. 2012; 145: 485-92.

15. Bray M. Pathogenesis of viral hemorrhagic fever. Curr Opin Immunol. 2005; 17: 399-403.

16. Hensley LE, Young HA, Jahrling PB, Geisbert TW. Proinflammatory response during Ebola virus infection of primate models: possible involvement of the tumor necrosis factor receptor superfamily. Immunol Lett. 2002; 80: 169-79.

17. Paessler S, Walker DH. Pathogenesis of the viral hemorrhagic fevers. Annu Rev Pathol. 2013; 8: 411-40.

18. Sanchez-Cordon PJ, Pedrera M, Risalde MA, Molina V, Rodriguez-Sanchez B, Nunez A, et al. Potential Role of Proinflammatory Cytokines in the Pathogenetic Mechanisms of Vascular Lesions in Goats Naturally Infected with Bluetongue Virus Serotype 1. Transbound Emerg Dis. 2013; 60: 252-62.

19. Marin-Lopez A, Otero-Romero I, de la Poza F, Menaya-Vargas R, Calvo-Pinilla E, Benavente J, et al. VP2, VP7, and NS1 proteins of bluetongue virus targeted in avian reovirus muNS-Mi microspheres elicit a protective immune response in IFNAR(-/-) mice. Antiviral Res. 2014; 110: 42-51.

20. Ortego J, de la Poza F, Marin-Lopez A. Interferon alpha/beta receptor knockout mice as a model to study bluetongue virus infection. Virus Res. 2014; 182: $35-42$.

21. Calvo-Pinilla E, Navasa N, Anguita J, Ortego J. Multiserotype Protection Elicited by a Combinatorial Prime-Boost Vaccination Strategy against Bluetongue Virus. PLoS One. 2012; 7: e34735.

22. Rojas JM, Rodriguez-Calvo T, Pena L, Sevilla N. T cell responses to bluetongue virus are directed against multiple and identical CD4(+) and CD8(+) T cell epitopes from the VP7 core protein in mouse and sheep. Vaccine. 2011.

23. Ratinier M, Caporale M, Golder M, Franzoni G, Allan K, Nunes SF, et al. Identification and characterization of a novel non-structural protein of bluetongue virus. PLoS Pathog. 2011; 7: e1002477.

24. Legisa DM, Perez Aguirreburualde MS, Gonzalez FN, Marin-Lopez A, Ruiz V, Wigdorovitz A, et al. An experimental subunit vaccine based on Bluetongue virus 4 VP2 protein fused to an antigen-presenting cells single chain antibody elicits cellular and humoral immune responses in cattle, guinea pigs and IFNAR(-/-) mice. Vaccine. 2015; 33: 2614-9.

25. Ma G, Eschbaumer M, Said A, Hoffmann B, Beer M, Osterrieder N. An equine herpesvirus type 1 (EHV-1) expressing VP2 and VP5 of serotype 8 bluetongue virus (BTV-8) induces protection in a murine infection model. PLoS One. 2012; 7: e34425.

26. Caporale M, Di Gialleonorado L, Janowicz A, Wilkie G, Shaw A, Savini G, et al. Virus and host factors affecting the clinical outcome of bluetongue virus infection. J Virol. 2014; 88: 10399-411.

27. Nomikou K, Hughes J, Wash R, Kellam P, Breard E, Zientara S, et al. Widespread Reassortment Shapes the Evolution and Epidemiology of Bluetongue Virus following European Invasion. PLoS Pathog. 2015; 11: e1005056.

28. Giulietti A, Overbergh L, Valckx D, Decallonne B, Bouillon R, Mathieu C. An overview of real-time quantitative PCR: applications to quantify cytokine gene expression. Methods. 2001; 25: 386-401.

29. Coetzee P, van Vuuren M, Venter EH, Stokstad M. A review of experimental infections with bluetongue virus in the mammalian host. Virus Res. 2014; 182: 21-34

30. Calvo-Pinilla E, Rodriguez-Calvo T, Anguita J, Sevilla N, Ortego J Establishment of a bluetongue virus infection model in mice that are deficient in the alpha/beta interferon receptor. PLoS ONE. 2009; 4: e5171.

31. Calvo-Pinilla E, Nieto JM, Ortego J. Experimental oral infection of bluetongue virus serotype 8 in type I interferon receptor-deficient mice. J Gen Virol. 2010; 91: 2821-5.

32. McColl KA, Gould AR. Bluetongue virus infection in sheep: haematological changes and detection by polymerase chain reaction. Aust Vet J. 1994; 71: 97-101.

33. Howerth EW, Greene CE, Prestwood AK. Experimentally induced bluetongue virus infection in white-tailed deer: coagulation, clinical pathologic, and gross pathologic changes. Am J Vet Res. 1988; 49: 1906-13.

34. Umeshappa CS, Singh KP, Nanjundappa RH, Pandey AB. Apoptosis and immuno-suppression in sheep infected with bluetongue virus serotype-23. Vet Microbiol. 2010; 144: 310-8.
35. Darpel KE, Monaghan P, Simpson J, Anthony SJ, Veronesi E, Brooks HW, et al. Involvement of the skin during bluetongue virus infection and replication in the ruminant host. Vet Res. 2012; 43: 40.

36. Lee F, Chen JL, Lin CM, Wang FI. Presence of bluetongue virus in the marginal zone of the spleen in acute infected sheep. Vet Microbiol. 2011; 152: 96-100.

37. Schwartz-Cornil I, Mertens PP, Contreras V, Hemati B, Pascale F, Breard E, et al. Bluetongue virus: virology, pathogenesis and immunity. Vet Res. 2008; 39:

38. Umeshappa CS, Singh KP, Ahmed KA, Pandey AB, Nanjundappa RH. The measurement of three cytokine transcripts in naive and sensitized ovine peripheral blood mononuclear cells following in vitro stimulation with bluetongue virus serotype-23. Res Vet Sci. 2011; 90: 212-4.

39. Drew CP, Heller MC, Mayo C, Watson JL, Maclachlan NJ. Bluetongue virus infection activates bovine monocyte-derived macrophages and pulmonary artery endothelial cells. Vet Immunol Immunopathol. 2010; 136: 292-6.

40. Reiss CS, Komatsu T. Does nitric oxide play a critical role in viral infections? J Virol. 1998; 72: 4547-51.

41. Dhanasekaran S, Vignesh AR, Raj GD, Reddy YK, Raja A, Tirumurugaan KG. Comparative analysis of innate immune response following in vitro stimulation of sheep and goat peripheral blood mononuclear cells with bluetongue virus - serotype 23. Vet Res Commun. 2013; 37: 319-27.

42. Umeshappa CS, Singh KP, Nanjundappa RH, Channappanavar R, Maan S, Maan NS. Bluetongue virus - 23 stimulates inducible nitric oxide synthase expression and nitric oxide production in mononuclear cells of blood and/or regional lymphoid organs. Vet Res Commun. 2012; 36: 245-50.

43. Burggraaf S, Bingham J, Payne J, Kimpton WG, Lowenthal JW, Bean AG. Increased inducible nitric oxide synthase expression in organs is associated with a higher severity of H5N1 influenza virus infection. PLoS One. 2011; 6: e14561.

44. Basu A, Chaturvedi UC. Vascular endothelium: the battlefield of dengue viruses. FEMS Immunol Med Microbiol. 2008; 53: 287-99.

45. Marty AM, Jahrling PB, Geisbert TW. Viral hemorrhagic fevers. Clin Lab Med. 2006; 26: 345-86, viii.

46. Lentsch $\mathrm{AB}$, Ward PA. Regulation of inflammatory vascular damage. J Pathol. 2000; 190: 343-8.

47. Mortola E, Noad R, Roy P. Bluetongue virus outer capsid proteins are sufficient to trigger apoptosis in mammalian cells. J Virol. 2004; 78: 2875-83.

48. Nagaleekar VK, Tiwari AK, Kataria RS, Bais MV, Ravindra PV, Kumar S. Bluetongue virus induces apoptosis in cultured mammalian cells by both caspase-dependent extrinsic and intrinsic apoptotic pathways. Arch Virol. 2007; 152: 1751-6.

49. Stewart ME, Roy P. Role of cellular caspases, nuclear factor-kappa B and interferon regulatory factors in Bluetongue virus infection and cell fate. Virol J. 2010; 7: 362.

50. Hengartner MO The biochemistry of apoptosis. Nature. 2000; 407: 770-6.

51. Liang Y, Yan C, Schor NF. Apoptosis in the absence of caspase 3. Oncogene. 2001; 20: 6570-8 